\title{
The young Sporophytes of Lycopodium complanatum and Lycopodium clavatum.
}

\author{
BY
}

GRACE WIGGLESWORTH, M.SC.

University of Manchester.

With Plate XXII and four Diagrams in the Text.

THE Lycopodiaceae occupy a somewhat isolated position among the 1 plants of the present day, especially as regards their anatomy, and compared with other groups of vascular Cryptogams they have received much less attention. Their relationship to other groups is a problem still unsolved, although the careful investigation of Palaeozoic plants has considerably extended our knowledge of the Lycopodiales in general. The present paper deals only with the anatomy of the young sporophyte of Lycopodium. How far we can rely on the evidence afforded by the early stages in the development of the young plant, as recapitulating the history of the group to which it belongs, is a debatable question, but that ancestral characters are shown in some cases during the early stages of life seems probable, and this fact alone makes the study of young forms a highly interesting one.

A brief summary of the literature dealing with the morphology and anatomy of the stem of Lycopodium is given by $\mathrm{Mr}$. C. E. Jones ${ }^{1}$ in a paper read before the Linnean Society in April, 1904, in which he refers to the contributions on this subject made by Nägeli, Hegelmaier, Cramer, Sachs, Russow, Strasburger, David and Weber, Pritzel, Linsbauer, and Boodle. Mr. Jones deals chiefly with a comparison of the mature stems of different species of Lycopodium. He considers that the development of anatomical structure has proceeded along two lines. L. clavatum may be taken as a type of the group in which a series of alternating bands of xylem and phloem is developed. This form of vascular structure is characteristic of those Lycopods which have creeping stems. In the other forms, of which $L$. squarrosum may be taken as a type, the phloem is scattered through the mass of xylem in more or less isolated patches. This structure is characteristic of tropical epiphytes.

1 Jones, The Morphology and Anatomy of the stem of the Genus Lycopodium. Trans. of the Linnean Soc., March, $19{ }^{\circ} 5$.

[Annals of Botany, Vo1. XXI. No. LXXXII. April, 1907.] 
Mr. Jones also gives a short account of the structure of the stem of the 'seedling' of L.clavatum, and young plants derived from the bulbils of $L$. Sclago and L. serratum. The structure of the roots was not worked out in any detail.

References to the anatomy of the young sporophyte of Lycopodium have been made previous to those of Jones. As early as 1873 Fankhauser $^{1}$ examined young sporophytes of $L$. annotinum, and found that the primary vascular strand sent off a short branch to the foot, but he apparently did not trace the changes in the stele throughout the plantlet. The most complete account of the morphology and anatomy of the young sporophyte is that given by Bruchmann ${ }^{2}$ in his paper ' Über die Prothallien und die Keimpflanzen mehrerer europäischer Lycopodien, \&c.' He describes the development of the embryo, and some important points in the structure of the young sporophytes of $L$. clavatum, giving a brief description of the root and the stem. He figures a transverse section of the stem of a young plant, showing a tetrarch arrangement of xylem and the origin of a rootlet. Other forms, such as L. complanatum and Selago, are dealt with, but not in such detail with regard to their anatomy. A brief description is given of $L$. complanatum, and a series of beautiful figures showing the external structure and attachment to the prothallus. He also describes the formation of pseudo-adventitious buds in this form, and enters fully into the branching of the roots.

The material for this investigation was obtained from Dr. Bruchmann, who had very kindly sent a series of prothallia and sporophytes, for the Manchester Museum, to Professor Weiss, and it was thought that it might serve a useful purpose to make a detailed examination of some of the duplicate material.

Two sporophytes of $L$. complanatum were examined, one still attached to the prothallus, about $3.1 \mathrm{cms}$. long; the other considerably older-about $9 \mathrm{cms}$. long (Pl. XXII, Figs. I and 2). Two sporophytes of L. clavatum, at about the same stages of development, were also examined for comparison with those of $L$. complanatum.

\section{External Features.}

The younger plantlet of $L$. complanatum (Fig. I) had evidently not appeared above the surface of the ground. The short stem and first root are seen emerging from the upper side of the top-shaped prothallus, bent approximately at right angles to one another, and both considerably curved. The root has branched three or four times, but the stem is unbranched, and bears a number of small scale-like leaves, spirally arranged and at varying distances from one another.

\footnotetext{
1 Fankhauser, Botanische Zeitung, Jan., I873, p. 1.

2 Bruchmann, Über die Prothallien und die Keimpflanzen mehrerer europäischer Lycopodien, \&c., I 898.
} 
The other plantlet (Fig. 2) is at a much more advanced stage of growth ; there is no trace of prothallus visible to the naked eye, but the foot is plainly visible as a round warty knob at the base of the stem ( $f t, \mathrm{Pl}$. XXII, Fig. 2). The stem has branched several times, and just below the first bifurcation is an adventitious root which has already branched three times. Numerous leaves clothe the stem; the upper leaves are green and provided with vascular strands, the lower are scale-like. Just above the foot a small prominence $(p . a$. in Pl. XXII, Fig. 2) marks the position of a 'pseudoadventitious bud,' which although of such minute size shows, in a series of transverse sections which were made in this region, dichotomy at the apex of the stem, and a root has already pushed its way through the cortex, and appears as a slight projection at the side of the bud.

\section{Internal Structure.}

A. The Root System.

(a) First root. The material at hand was not suitable for working out the embryonic development of the first root. The investigations of Treub and Bruchmann show that the primary root is absent in those forms of Lycopodium which they examined. Treub ${ }^{1}$ found that in L. cermum the first root arises in the interior of the embryonic tubercle; Bruchmann ${ }^{2}$ found that in the case of $L$. clavatam it arises endogenously from the hypocotyl, and the latter states that in Lycopodium and Selaginella the primary root is rudimentary, and the first functional root is merely one of the endogenous lateral roots developed on the embryonic axis. I shall use the term first root, therefore, to refer to the first functional root.

In $L$. complanatuim the first root comes off laterally, almost at right angles to the stem, immediately above the foot region (see $r^{\prime}, \mathrm{Pl}$. XXII, Figs. I and 2). The apex was broken off in both sporophytes I examined, but sections nearest the tip show two somewhat bow-shaped groups of tracheides with smaller elements at the periphery, usually more or less collected at the free ends of the bow ( $p x$, Pl. XXII, Fig. 3$)$; between the two xylem groups lies a strand of phloem occupying the centre of the stele. This agrees in the main with the arrangement described by Bruchmann for the first root of $L$. clavatum, and with that noted by Jones ${ }^{3}$ as occurring in a section marked 'first root' which was shown to him as that of L. clavatum. Bruchmann calls this a diarch arrangement; Jones says that it may be regarded as diarch or tetrarch. I am inclined to think that this arrangement is more correctly described as diarch.

1 Trenb, Annales de Buitenzorg, vol. iv, p. I33, and Pl. XVIII.

${ }^{2}$ Bruchmann, Über die Prothallien und die Keimptlanzen mehrerer europäischer Lycopodien, I 898 , p. 49 and also p. 55 .

3 Jones, loc. cit., p. 26. 
Many sections show a few small, apparently protoxylem elements on the outer side of the middle of the bows of xylem elements (see $p x, \mathrm{Pl}$. XXII, Fig. 3), but much variation exists with regard to the position of these elements. In only one case was the differentiation of the xylem traced in the apical region of a root which showed this two-grouped arrangement of xylem; here xylem elements first appeared at three points, but very soon a row of small elements united two, and the third was extended by the formation of more protoxylem ( $p x$, Pl. XXII, Fig. 4 ) into another row, separated from the former by thin-walled elements, some of which, by their larger size and absence of contents, indicate the formation of metaxylem elements ( $m x$, Fig. 4). This arrangement appears to be distinctly diarch.

In a rather older sporophyte (Fig. 2) the main root, a little way behind the apex, shows a similar structure to that described above, except that the two xylem groups have united at one end to form a crescentshaped mass enclosing a central phloem group (Pl. XXII, Fig. 5). The point of union of the two xylem masses is marked by a group of small elements. From this group, a little nearer the base of the root, a somewhat smaller branch passes off to a rootlet, which, though slighter, appears to have originated by dichotomy, and receives a somewhat crescent-shaped mass of xylem (see Fig. 6). Lower down the crescent-shaped mass of xylem in the main root divides again into two groups separated by phloem, and closely resembling the arrangement shown in Fig. 3. It does not seem necessary for these two xylem masses to unite before giving off a branch to a rootlet, as the tracheides may sometimes be seen coming off from one, only, of the xylem masses (see P1. XXII, Figs. 7 and 8), and sometimes from the two separate groups; in the last case the two smaller groups of xylem which pass into the smaller branch may unite immediately to form a single group.

It will be observed that the branching of the root has been described as dichotomy above. Van Tieghem and Douliot consider that in Lycopodium the branches arise immediately behind the apex, but Bruchmann ${ }^{1}$, who has studied the branching of the roots in detail, finds that a pure or modified form of dichotomy takes place in the roots of the Lycopodiaceae. $\mathrm{He}$ figures longitudinal sections through apices of roots of $L$. complanatum showing dichotomy.

A number of sections made through the roots of $L$. complanatum and L. clavatum supported the view that a modified form of dichotomy occurred. It appears that at first one branch of the dichotomy is only slightly developed, while the other continues to bore its way straight down into the soil ; gradually, however, the branches get more and more equal, until finally two equal branches occur. These branches appear irregularly arranged on all sides, and they in their turn branch again in a similar manner.

\footnotetext{
1 Bruchmann, loc. cit., pp. 73 and 74 , Figs. 32, 33, 34, Taf. V.
} 
Near the base of the first root of $L$. complanatum transverse sections show three groups of tracheides with phloem in the centre and extending between the xylem groups (P1. XXII, Fig. 9). Sometimes two of the three groups unite, cutting up the phloem into a larger and smaller mass, but in both sporophytes of $L$. complanatum examined three separate groups of tracheides occurred in sections nearest the foot. Thus a change from diarch to triarch structure takes place in the first root. A similar change from two to three groups of xylem occurs in $L$. clavatum, where it was traced out and showed that one of the two groups of xylem became elongated laterally and a third group separated off from this. In this species a plantlet at about the same stage of development as the older sporophyte of L. complanatum (Pl. XXII, Fig. 2) showed much the same arrangement of xylem and phloem, except that sections nearest the tip showed only a single group of xylem with phloem at one side, i.e. a collateral or monarch arrangement. Thus we may get one, two, and three groups of xylem in the first root.

Immediately surrounding the vascular elements is a layer of cells which is clearly of cortical origin (see Pl. XXII, Figs. 3, 5, 6, and 9, cells marked $x$ ). This layer is called the pericambium by Bruchmann; the cells are irregular in shape, and some of the walls show signs of lignification, but in others this feature is absent; sometimes the cells are considerably smaller and more rounded in shape than those of the surrounding cells, in which case they resemble more nearly the parenchymatous cells of the central cylinder. The pericambium is surrounded by an irregular band of cells, two or three cells in thickness, with walls lignified on all sides forming a protective sheath; there is no distinct boundary between these two layers. Outside the protective sheath in the younger parts of the root lie two or three layers of large thin-walled cells with, here and there, small intercellular spaces. At the periphery is the piliferous layer consisting of similar thin-walled cells, some of which have grown out into root-hairs. (In L. clavatum the hairs are in groups of three or four, each group being formed from single epidermal cells.) De Bary ${ }^{1}$ states that only in Lycopodium can special hair-cells be distinguished from other epidermal cells of the root, and goes on to describe the formation of groups of hairs from a part of the lower end of an epidermal cell, which is cut off by an oblique wall as a small cell, and undergoes division into 2-4 cells, each of which grows out into a root-hair. This evidently is the case in L. clavatum, but not in L. complanatum. Nearer the base of the root, the cells lying next to the protective sheath, to the extent of one or two layers, have very much thickened walls and small lumina (Pl. XXII, Fig. 9), these are surrounded by large thin-walled cells with here and there, just without the thick-walled zone, intercellular spaces, 
sometimes of considerable size (see i.s., P1. XXII, Fig. 9). These air-spaces are apparently produced by the breaking down of the cortical cells ; they do not occur throughout the root.

Air-spaces of any considerable size, formed by the breaking down of the cortical cells, are not of frequent occurrence in roots of terrestrial plants. According to Bower ${ }^{1}$ air-spaces occur in the internal roots of $L$. Selago, where the outer cortex may be completely separated from the inner cortex by an air-space of schizogenetic origin. He also considers it probable that the outer air-space in Stigmarian rootlets was formed in the same way; and considering the possible relationship of these forms, they may mark the retention of an ancestral character in the Lycopodiaceae from a more aquatic ancestry, though not necessarily from Lepidodendreae.

(b) The second and following roots. The second and following roots arise endogenously in the apical region of the stem. Bruchmann ${ }^{2}$ has studied the origin of the roots in the stems of the Lycopodiaceae, particularly in L. imundatum, and found that they arise endogenously in acropetal order from several layers in the cortex, on the ventral side of the stem. He figures a transverse section of the stem of L. clavatum showing the origin of the root in these layers. Van Tieghem and Douliot ${ }^{3}$, who also studied the origin of the roots of Lycopodiaceae, agreed with Bruchmann with regard to their endogenous origin, but came to a different conclusion as regards the exact layers of the stem which participate in their formation. They consider that the pericycle (pericambium) alone gives rise to the roots.

The young sporophytes of $L$. clavatum show very clearly the endogenous origin of the roots. One of those I examined, the stem of which was about $2 \mathrm{cms}$. long, showed no less than five rootlets which had not pushed their way out into the soil ; they appeared as masses of cells with dense protoplasmic contents and large nuclei in the inner cortex. The exact layers in which they originated could not be traced, as the apical portion of the stem, in which this must be looked for, was destroyed.

Whilst agreeing in the absence of a primary root, the Lycopodia differ from Selaginella with respect to the origin of the roots, which in the latter, apparently, do not arise directly from the stem in the apical region, but are developed endogenously from exogenous organs (rhizophores), which are found at the base of the stem and at the bifurcations ${ }^{4}$. In this respect the condition in Selaginella might be regarded as intermediate between that of Lycopodium and Phylloglossum, for in the latter the roots arise exogenously.

${ }^{1}$ Bower, On the Structure and Anatomy of the axis of Lepidostrobus Brownii. Annals of Botany, vol. vii, $\mathbf{1} 893$, p. 33 I.

${ }^{2}$ Bruchmann, loc. cit, p. 75 , and Pl. IV, Fig. 3 r.

${ }^{3}$ Van Tieghem and Douliot, Ann. des Sc. Nat., $7^{\mathrm{e}}$ sér., T. viii, p. 553.

${ }_{4}$ Bruchmann, Untersuchungen iiber Selaginella spimulosa, 1897 . 
The second and following roots of the young sporophytes of $L$. complanatum and $L$. clavatum show a diarch arrangement at their base and throughout the greater part of their length, similar to that shown in Pl. XXII, Fig. 3, while after dichotomy the arrangement may be monarch. The two strands of xylem connect up with two tracheid groups of the stem as shown in P1. XXII, Fig. II. The growth of these roots appears to be retarded at first, and, as mentioned above, a whole row of young rootlets which have not grown out beyond the inner layers of the cortex may be seen in the young sporophyte. When favourable conditions for their development arise they push their way out through the cortex, generally more or less at right angles to the stele of the stem. Fig. Io shows one of these young rootlets in the stem of L. complanatum just above the foot region.

The older sporophyte of L. clavatum was interesting, as it showed a rootlet which had travelled for some distance down the cortex of the stem $(r t$., P1. XXII, Fig. 4) almost parallel with the axis, instead of pushing its way directly to the periphery, and in this respect it resembles the upright $L$. Selago and such forms as $L$. serratum, L. tetragonum, L. reflexum, $L$. squarrosum, in which the occurrence of rootlets running through the cortex have been recently noted by Jones ${ }^{1}$. Referring to the rootlets in $L$. serratum, Jones ${ }^{2}$ says that if the stem is growing quite erect the roots do not pass out, but gradually die out, and that only when the stem is growing obliquely do the roots emerge. The lower part of the stem of the young sporophyte of $L$. clavatum which contained the rootlet running down the cortex was bent at frequent intervals, and possibly the part in which the rootlet occurred was running in an almost upright direction, and this might partly account for its direction. It arose a short distance above the foot, and was the third root, in point of age, proceeding from the stem. The second and fourth roots grew more or less at right angles to the stem. The roots seem to be strongly geotropic, although in some cases other forces, possibly moisture and chemical attraction of other substances in the soil, act more strongly than gravity, and cause them to grow in a different direction. With regard to the internal structure of the rootlet in question, the differentiation of the vascular elements had begun; two curved rows of narrow tracheides were discernible separated by thin-walled cells, some of which by their large size and absence of contents indicated metaxylem. The two groups of xylem elements were connected up with two groups of tracheides in the main axis (see Pl. XXII, Fig. II), and in this respect resembled the roots running through the cortex of adult forms previously described. In the latter the two xylems usually join up, forming a crescentshaped mass with small protoxylem elements at the tips of the crescent, but this is not always the case, for in a short piece of stem of $L$.dichotomum 
which I examined, and which contained numerons (as many as seventy) roots in the cortex, in one or two cases the xylems had not joined up to form the crescent-shaped mass on leaving the main stele, but remained separate, resembling those of the rootlet shown in Pl. XXII, Fig. 3 ; and Jones also noted a few similar cases. Thus the root running through the cortex does not differ materially from the other roots of the young sporophyte as far as the vascular structure is concerned.

(c) Comparison of the vascular structure of the root of mature plants of L. clavatum, L. complanatum, and other Lycopodiaceae with that of the young Sporophytes. In the adult plants of $L$. clavatum and complanatum a polyarch vascular bundle is found in the root; the arrangement is radial with the xylem plates often united in the centre. Unequal branching, however, results in the formation of slender branches bearing a much smaller number of xylem groups, and in the finest branches of all a monarch or collateral arrangement occurs. The root of the young sporophyte resembles some of these finer ramifications of the roots of the adult plants in its vascular structure. In $L$. Selago and $L$. imundatum, according to Russow and others, the xylem is diarch and the two masses unite into a single one, which is crescentic in shape, with the phloem in the hollow of the crescent. Jones ${ }^{1}$ also found that in the greater number of the roots which run through the stems of such species as L. Selago, L. serratum, $L$. squarrosum, a similar arrangement occurs, although in a few cases, as mentioned above, the two xylem groups remain separate. In Engler and Prantl's ${ }^{2}$ Pflanzenfamilien a figure of the stem of L. Phlegmaria is shown, in which there is a rootlet in the cortex, with three groups of xylem united in the centre. This arrangement approaches that occurring at the base of the first root of the young sporophytes of $L$. clavatum and complanatum, but differs in having all the xylem groups united in the centre, a condition which is found in the upper part of the stems of the young sporophytes and in slender branches of the adult stem of L. complanatum.

According to Campbell ${ }^{3}$, who takes Bertrand as his authority, the root of Phylloglossum is diarch, but Bower ${ }^{4}$, in his paper on Phylloglossum read before the Royal Society in 1885 , describes and figures a monarch or collateral root. Some specimens of this interesting plant which I had the opportunity of examining, as a number had been sent to Prof. Weiss from New Zealand, showed a monarch root-structure similar to that described by Bower, but in one case a structure very similar to that occurring in L. Selago appeared-a crescent-shaped mass of xylem with small elements

1 Jones, loc. cit., pp. 28 and 29.

2 Engler and Prantl, Pflanzenfamilien, vol. iv, p. 5 59 , Fig. 365 .

3 Campbell's Mosses and Ferns (new edition), p. 503 .

${ }^{4}$ Bower, Phylloglossum Drummondi. Phil. Trans. R. Soc., 1885, Part II, p. 674. 
at the tips of the horns of the crescent (see Pl. XXII, Fig. 20), possibly indicating that the monarch condition, usually found, is a derived one.

On the whole, the vascular arrangement obtaining in the roots of the young sporophytes resembles more nearly that found in those forms which have roots running through the cortex of the stem, such as L. Selago, differing however in the fact that the two xylem groups do not join up immediately behind the point where they join the stele of the stem, as is usually the case with the internal rootlets. It is clear, however, that the monarch condition occurring in certain parts of the root is brought about by the joining-up of the xylem on one side of the stele, and not by the abortion of part of the phloem, as appears to be the case in roots of certain of the Ophioglossaceae, e.g. $O$. vulgare, O. bulbosum, $O$. reticulatum, which according to Van Tieghem ${ }^{1}$ have diarch arrangement near their insertion, but only one of the lateral phloem groups is developed.

\section{B. The Foot Region.}

The foot of $L$. complanatum is a rounded structure covered with warty protuberances, which, providing a greater surface, enable it to withdraw more nourishment from the surrounding prothallus. Apparently the foot remains for a considerable time after the disappearance of the prothallus. In the sporophyte shown in Pl. XXII, Fig. 2, where the prothallus has almost entirely disappeared, the cells of the foot are unimpaired even at the periphery, and this, together with the fact that a small branch of the vascular tissue passes into it, would show that there is some possibility that it still acted as an absorbing organ.

Treub ${ }^{2}$ considers that the 'embryonic tubercle' in $L$. cermum, leaving the prothallus and leading a kind of independent existence, represents the foot of the embryo, and that the papillae on the foot of L. Phlegmaria correspond to hairs on this embryonic tubercle. The tuber of Phylloglossum corresponds in position and structure to the parenchymatous tuber of $L$. cernum ; in both cases the tuber is composed of parenchymatous cells, and the superficial cells may develop root-hairs. Comparing the two, Bower ${ }^{3}$ remarks on the absence of a foot in Phylloglossum, but says 'it is to be remembered that in this plant the place of the foot is to be taken, physiologically if not morphologically, by the stalk of the young tuber.' The large parenchymatous cells, of which the foot of L. complanatum is mainly composed, are strongly pitted. The periphery is well defined in sections stained with haematoxylin, the walls appearing thicker than those of the internal cells on account of the thin layer of protoplasm which lines them. There are deep indentations between each cell, this again affording

1 Van Tieghem, Traité de Bot., Part II, p. I394.

2 Treub, Ann. de Buitenzorg, vol. v, p. I 28.

${ }^{3}$ Bower, Phil. Trans., I885, Part II, p. 675. 
1.



2

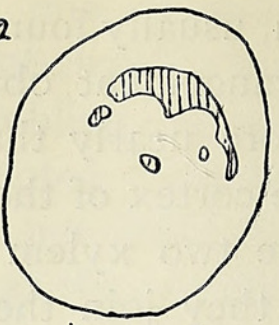

3.



4
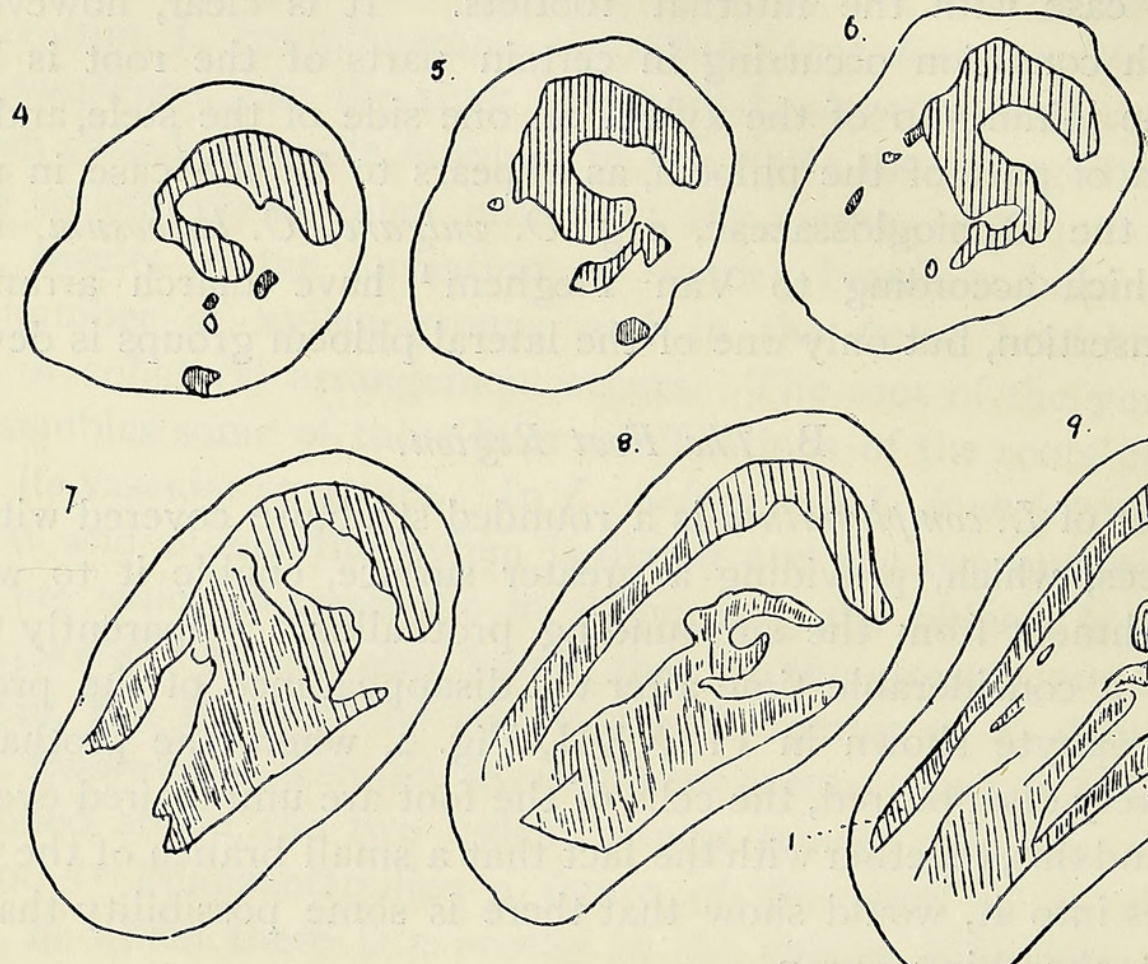

9.
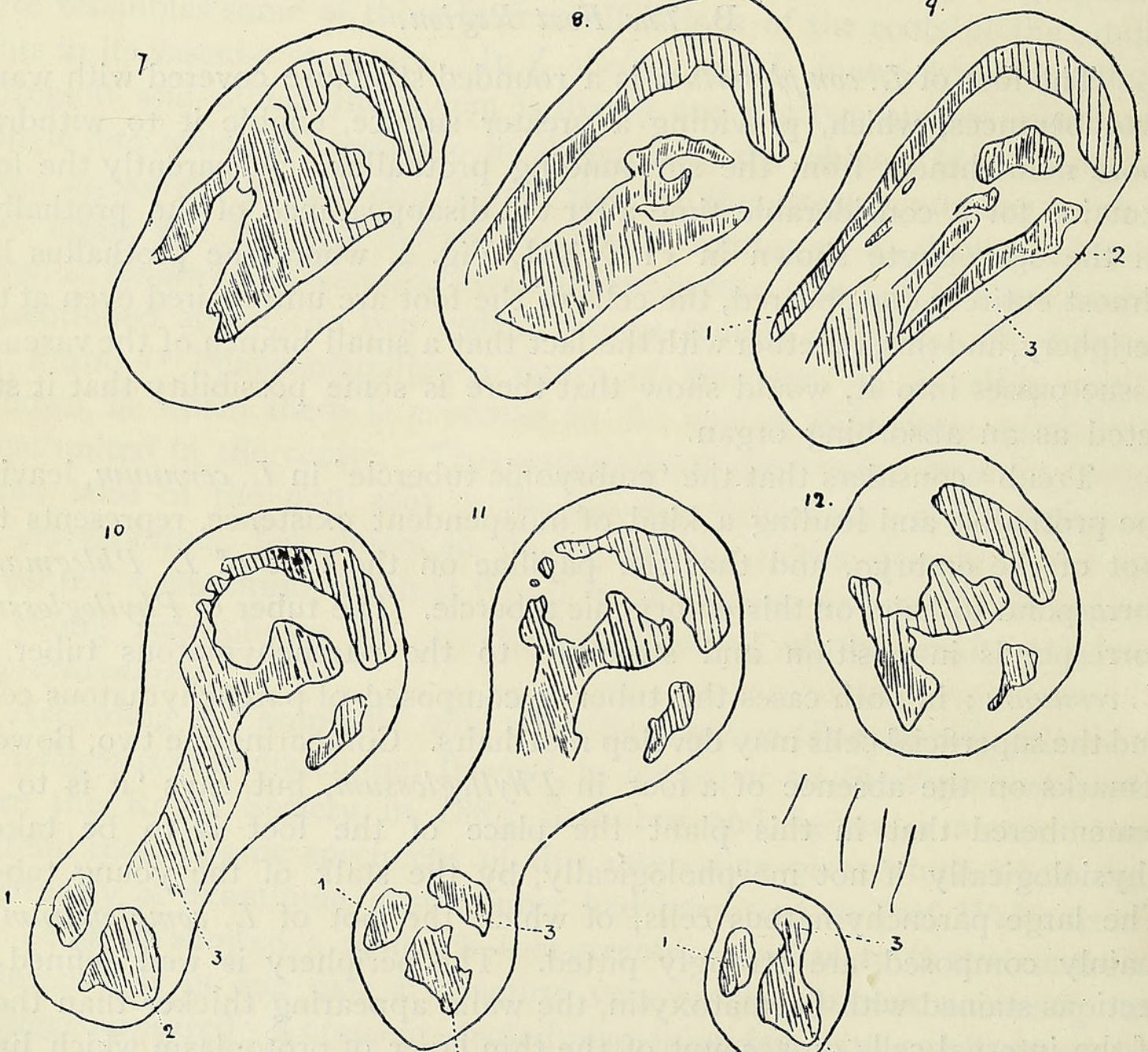

I

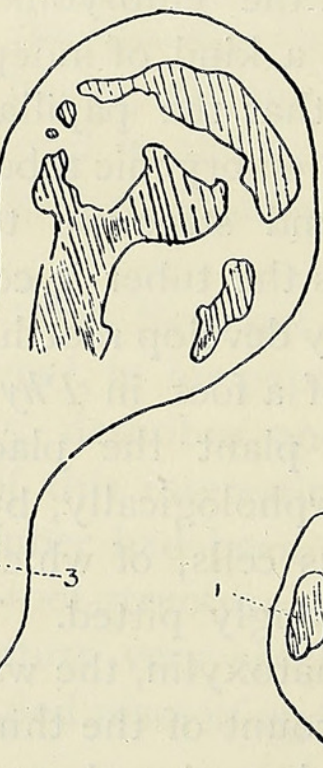

12.
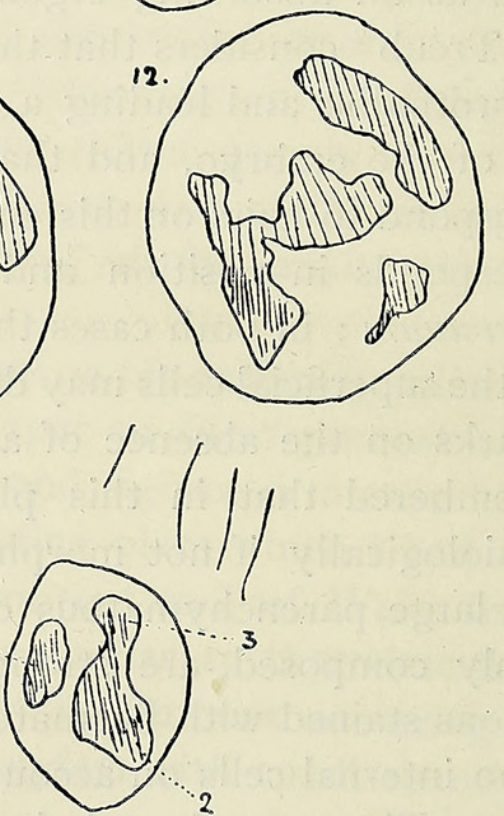

2

DIAGRAM I, Figs. I-I 2. Showing changes in the vascular arrangement in the foot region and base of the stem of L.complanatum (see Pl. XXII, Fig. 2) up to just above the point where the first root is given off, proceeding from below upwards. (P1. XXII, Fig. 12 shows the first appearance of xylem in the foot.) I, 2, and 3 in Figs. 9, I0, I I, 12 indicate the xylem strands which belong to the first root; in Fig. I 2 two of these have united. Shaded parts represent xylem. 
more absorptive surface. Series of transverse sections were made through the foot of both sporophytes of L.complanatum. Those of the older sporophyte, which were stained with iodine green and Bismarck brown, showed more clearly the rather thin-walled lignified cells which are connected with the 'protective sheath' of the stem and root than did the sections of the foot of the younger sporophyte, which were stained with haematoxylin and saffranin. Proceeding upwards from the base of the foot, the first appearance of lignification of the cell walls is shown in the centre of the foot, where about half a dozen cells took the iodine green stain. The area of this patch increases gradually, the cells appearing more or less uniform, with pitted lignified walls, until about twenty to thirty cells are included; then the lignification of the walls of the central cells becomes less and less until a distinct core of small thin-walled unlignified cells appear in the centre. A little higher up a tracheide appears a little to one side of this central patch (see $t, \mathrm{Pl}$. XXII, Fig. I2), and soon more tracheides are formed, until a bow-shaped group parallel with the periphery occurs (see Pl. XXII, Fig. I3). Diagram I (Figs. I-6) shows the further changes in the arrangement of the xylem of this vascular strand in the foot region of the older sporophyte of $L$. complanatum. It will be seen that three or four small groups of tracheides make their appearance in addition to the main group, but they vary in position, size, and number in the two sporophytes. There is, however, a tendency towards concentration of the xylems to form a somewhat crescent or hook-shaped mass of xylem (see Diagram I, Figs. 4, 5, 6, 7, 8, and 9) ; from this, three strands, I, 2, 3 (Figs. 9, 10, and II), pass off to the first root, and in the case of

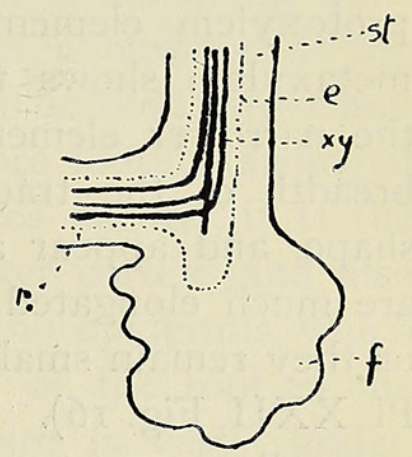

DIAGRAM 2. A diagrammatic sketch of a longitudinal section through the foot region of the young sporophyte of $L$. complanatum (see Pl. XXII, Fig. I) showing the course of the vascular strands. st, base of stem ; $r$, root ; $f$, foot ; $e$, protective sheath; $x y$, xylem strands.

the older sporophyte run in an upward direction, making an acute angle with the stele of the stem, and then turn at right angles to the main stem (see Diagram I, Figs. 3-12). In Fig. 12 it will be seen that two of the three strands have fused in the root.

In the younger sporophyte of $L$. complanatum the three xylem strands belonging to the root do not take an upward course, but pass off immediately at right angles to the stem (see Diagram 2).

In the young sporophytes of $L$. clavatum no vascular strand was observed in the foot. The smaller one showed two groups of xylem with a single strand of phloem throughout the root, but immediately above the foot, large vessels connected the two groups, separating the phloem into two portions, and very soon three groups of xylem separated out, the phloem between joining up and forming a three-rayed star. The older 
sporophyte showed three groups of xylem at the base of the root, but throughout the greater part of the foot region two of the groups united, but separated out again above the foot, forming an arrangement similar to that at the base of the root.

\section{Stem.}

(a) General structure. Transverse sections through the stem (PI. XXII, Figs. II, I4, I5) show that the centre is occupied by a single stele, which remains undivided except where branching occurs, and, as Mr. C. E. Jones ${ }^{1}$ points out, there is no evidence from the structure of the young sporophyte in favour of the view put forward by Strasburger that the central cylinder of Lycopodium may be regarded as gamostelic, in the ordinary sense of the word. The xylem consists of narrow spiral or annular protoxylem elements, which generally form bow-shaped groups. The metaxylem shows transitions from pitted to scalariform elements. In the narrower elements the pits appear rounded, and extend across the breadth of the tracheides, in the wider elements they are elliptical in shape, and appear as bordered pits, whilst in the widest elements they are much elongated in a radial direction, forming scalariform tracheides, or they remain small, several rows appearing on the longitudinal walls (see Pl. XXII, Fig. I6). The metaxylem elements are formed centripetally, and generally connect two or more of the groups of protoxylem. Near the foot region these groups may remain unconnected, the phloem occupying the central portion of the stele, as is usually the case with the root whether diarch or triarch, but at the point where the first root comes off a fusion usually occurs.

P1. XXII, Fig. I4 shows a transverse section of the lower part of the young sporophyte figured in P1. XXII, Fig. 2. Here it will be seen that the central mass of metaxylem has become quite separated off ; this, however, is not the usual condition; generally, the central metaxylem is connected with one or more protoxylem groups (see Diagram I, Fig. I2).

Alternating with the xylem groups are the phloem elements, consisting of sieve-tubes and parenchyma. The sieve-tubes are long and narrow; the walls appear to be covered with very finely pitted areas in older parts of the mature plant of $L$. complanatum. In this they agree with larger forms of Lycopodium, such as L. Hippuris, where the walls of the sieve-tubes have apparently sieve-plates, the pitted areas of which lie so close together that a reticulate appearance is given (see Pl. XXII, Fig. 21).

With regard to the contents of the sieve-tubes, negative results were obtained on testing for leptomin with guaiacum and hydrogen peroxide and with alpha naphtha dissolved in water and hydrogen peroxide; this may, 
however, be due to an insufficient quantity of this substance being present to be detected by these tests, as the sieve-tubes are very narrow.

The cells immediately surrounding the protoxylem are of cortical origin in the lower region of the stem, and also in the upper parts in those plantlets which have not appeared above the ground. The following regions can be distinguished external to the stele (see Pl. XXII, Fig. I4): (1) an irregular ring $(p c)$ of thin-walled, fairly large cells (pericambium), which abut on the xylem and phloem regions. Some parts of the walls of these cells show signs of lignification, so that it is often difficult to draw a distinct boundary between this and (2) the protective sheath (en), which immediately surrounds it, and which also consists of an irregular band of cells, one, two and occasionally three cells in thickness, the walls of which are not thickened but strongly lignified. Outside the protective sheath are (3) thick-walled cortical elements $(i c)$, closely packed cells, the walls of which show lignification at the corners in the neighbourhood of the protective sheath-cells. Proceeding outwards, the cells become larger and thinner-walled, gradually merging into (4) a much more loosely arranged layer of cells $(n c)$, in which large intercellular spaces occur. It is the presence of these large intercellular spaces in the outer cortex, and also the greater differentiation of cells forming the cortex and epidermis, which distinguish the basal region of the stem from that of the root in the neighbourhood of the foot, where the stelar structure is very similar. Bounding the cortex externally is (5) the epidermis $(e p)$, the cells of which vary in size, especially in the underground parts; their outer walls are thickened, and in the aerial parts numerous stomata occur.

(b) Changes occurring in the vascular structure. The arrangement of the xylem and phloem elements is subject to many changes, especially in the lower region of the stem, where the various obstacles met with in the soil have resulted in the stem taking a very irregular course. The strands of xylem are constantly uniting, then separating, or by extension of the protoxylem elements at the periphery of the stele a further subdivision may take place. There is, however, in the young sporophyte a tendency towards the formation of a solid core of xylem in the centre of the stele, and in the upper parts of the stem a more constant arrangement is maintained. Here a tri- or tetrarch condition occurs, large metaxylem elements in the centre uniting two groups of protoxylem, sometimes a third, and occasionally a fourth group. When all the groups are united the triarch condition resembles that occurring in the smaller branches of Psilotum and in young stems of Sphenophyllum in which secondary thickening has not begun.

Diagram 3, Figs. 1-10, shows the changes which occur in the arrangement of xylem and phloem in the younger sporophyte of $L$. complanatum, proceeding upwards from the point where the stele of the first root joins 
that of the stem, as seen in transverse sections. The xylem strands appear to have united in Fig. 2, but immediately above separate again, and an

1.

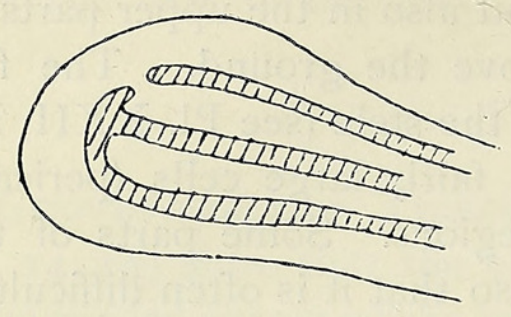

2

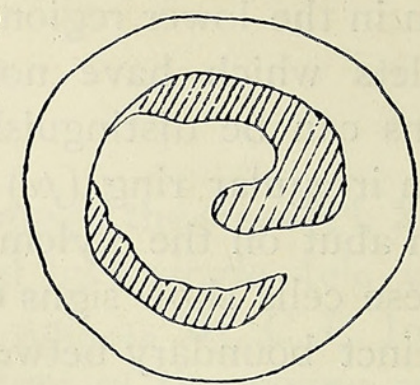

3

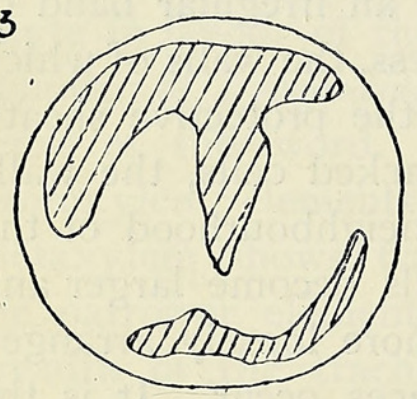

6.


4
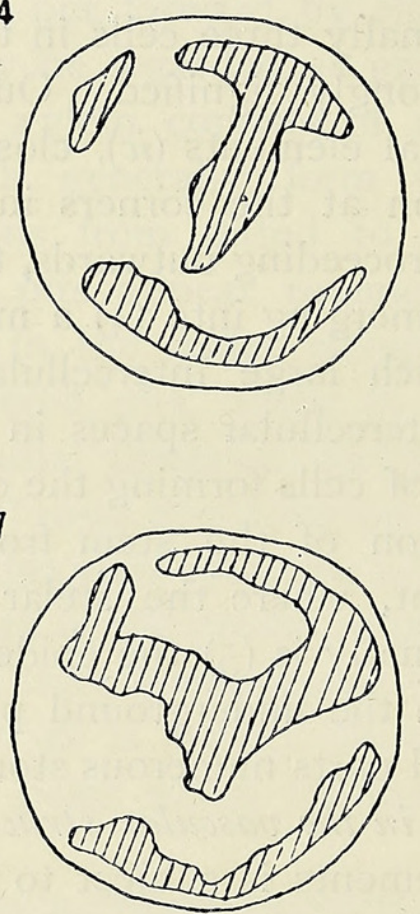

5

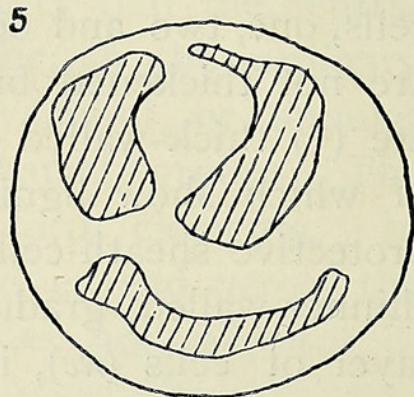

8

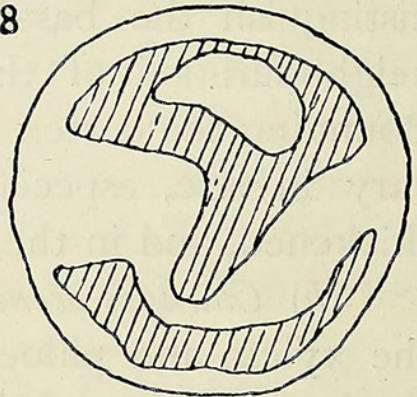

DIAGRAM 3, Figs. I-IO. Showing changes which take place in the vascular arrangement of the stem of the young sporophyte of L. complanatum (see Pl. XXII, Fig. I), proceeding from the base upwards. Fig. I shows three xylem strands passing off to the first root. Shaded parts represent xylem.

arrangement similar to that occurring in the root is found (Diagram 3, Figs. 4 and 5 ; and for root, Pl. XXII, Fig. 9). 
In the older sporophyte of $L$. complanatum a complication was brought about in the stelar arrangement, due to the fact that dichotomy had taken place very early; one of the branches had been arrested in its growth, forming what Bruchmann ${ }^{1}$ describes as a pseudo-adventitious bud, while the other was continued as the main stem and had again dichotomized several times. In the pseudo-adventitious bud, although this was only visible as a slight swelling near the foot, a root had already begun to grow out (Fig. I5). The apical growth of the branch had been much delayed, yet a stimulus to rapid growth had evidently been given, for the apex had just dichotomized, and the root was pushing through the outer layers of the cortex.

The changes in the arrangement of the xylem and phloem in the main stem of this second sporophyte were very rapid. In Diagram I, Figs. II and I2, and Diagram 4, Figs. I-23, some of the changes which occur in the first $2 \mathrm{~mm}$. of the stem region above the point where the first root comes off are shown. It will be seen that sometimes the xylem groups all unite, forming variously shaped masses (see Diagram 4, Figs. IO, II, I6, 20, 2I) ; sometimes islands of phloem are formed by the closing round of the xylem (see Diagram 4, Figs. 10, 16, 19, and 20), or the phloem may remain external to the xylem surrounding it, and forming numerous bays or cutting off smaller or larger portions, of various shapes (see Diagram 4, Figs. $18,19,22,23)$. There is, however, a tendency to the formation of a central mass of metaxylem. Diagram 4, Fig. 23, shows a section in which a central mass of metaxylem is separated off from three groups of smaller elements. As a rule, however, the central mass remains connected with at least one of the protoxylem groups.

In the sporophytes of L. clavatum there was less complication in the course of the xylem strand throughout the stem. A short distance above the point where the first root came off there were three separate groups of xylem, with phloem in the centre and extending between the groups; then one or two of the groups of xylem united at the periphery, apparently by extension of the protoxylem elements, and immediately after four groups separated out. Higher up two of the groups united again, by extension of protoxylem elements, and at the same time by centripetal development of metaxylem either all three groups united in the centre or one remained separate. The older sporophyte showed variations from the arrangement described above, in some parts of the upper portion of the stem, the protoxylem elements extending towards the centre in such a manner that a very irregular arrangement occurred, but on the whole the tendency was for the arrangement to become more uniform, producing a radial arrangement with the number of rays increased in the stouter portions of the stem and where dichotomy was about to take place.

1 Bruchmann, loc. cit., p. 7o. 
1.

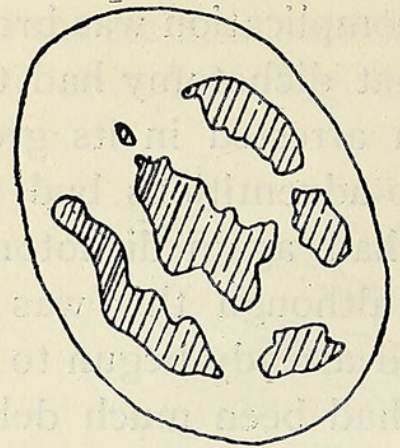

2.

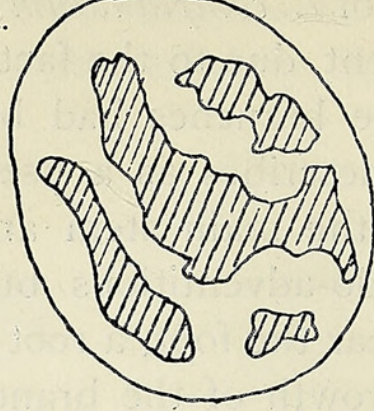

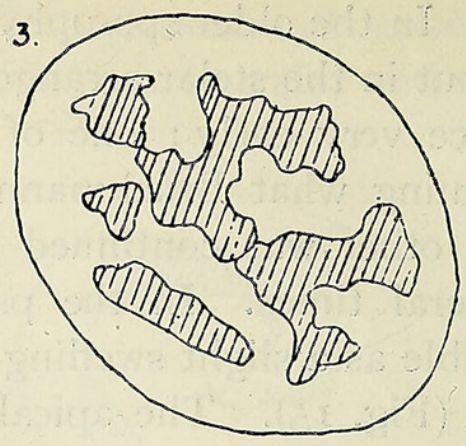

4
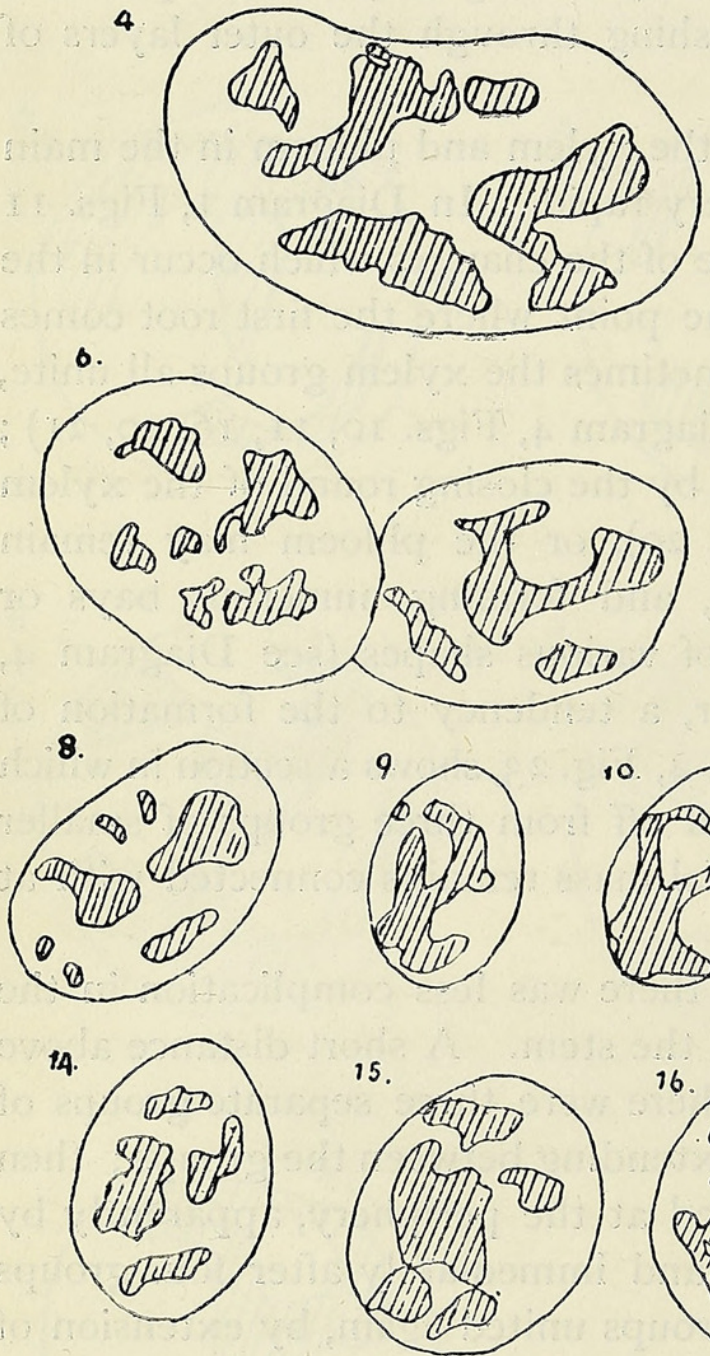
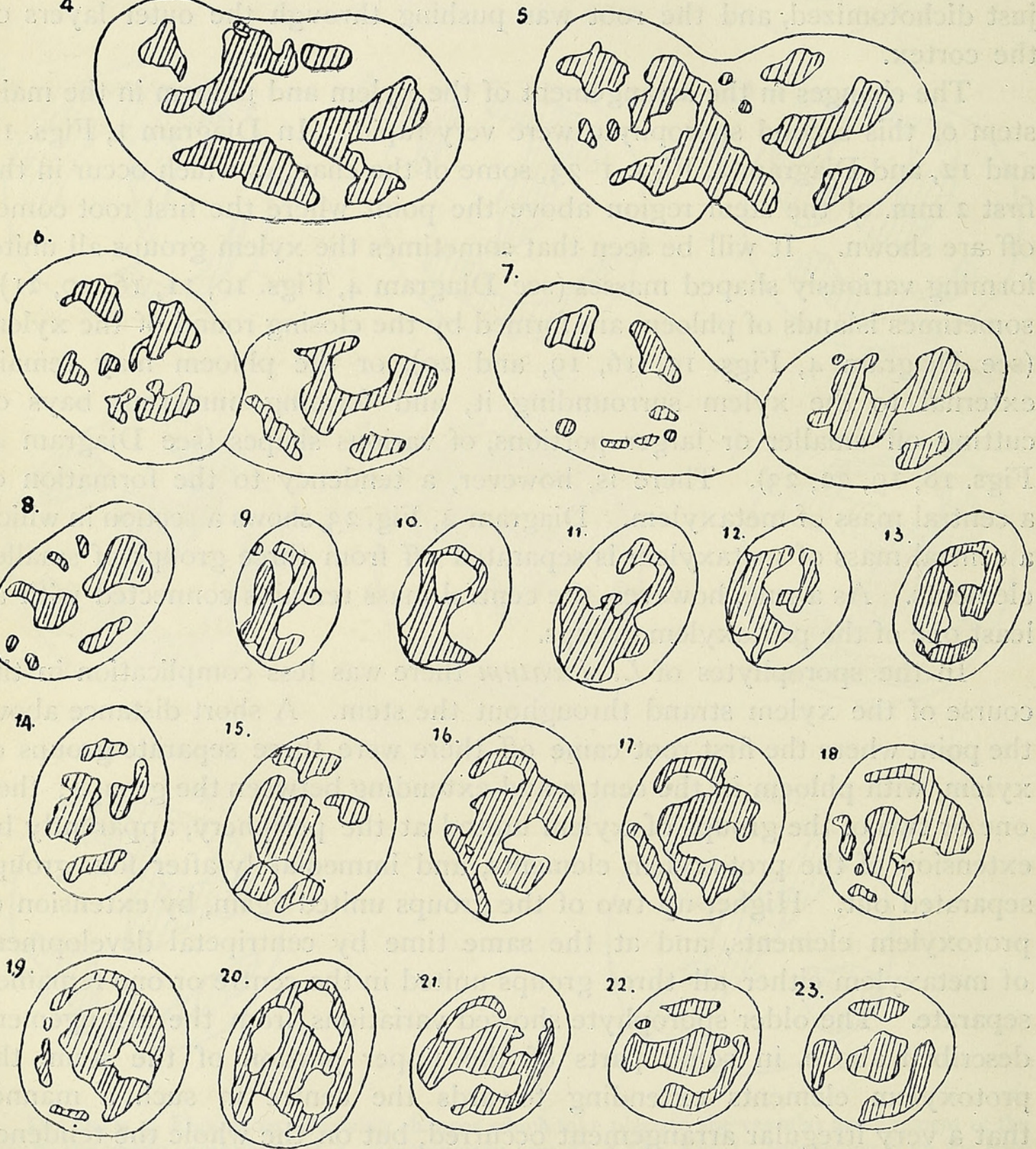

DiAgRAM 4. Showing some of the changes which take place in the vascular arrangement at the base of the stem of the young sporophyte of $L$. complanatum (see Pl. XXII, Fig. 2) above the point where the first root comes off. This continues the series of sections shown in Diagram I. Dichotomy is illustrated by the first seven figs.; the remaining, Figs. 8-23, show only the stele of the main branch, i.e. the right-hand one in Figs. 6 and 7 . (P1. XXII, Fig. I 5, represents a stage occurring between Diagram, Figs, 9 and 10.) ${ }^{\circ}$ Shaded parts represent xylem. 
In the upper part of the older sporophyte of $L$. complanatum a tendency towards the banded arrangement is shown; the xylem mass, which here is six-rayed, has become separated into two by a band of phloem. In this region also and in the older parts of L. clavatum a layer of cells occurs between the protoxylem and the 'pericambium,' which resemble the phloem-cells in general appearance and in the staining properties of the walls. Van Tieghem calls the band of cells, one to several layers thick, between the endodermis (protective sheath) and the xylem the pericycle, and regards it as part of the central cylinder. Strasburger and Bruchmann ${ }^{1}$, on the other hand, consider that this pericycle has the same origin as the cortex. I find that in the lower part of the stem the protoxylem elements do lie next to cells of cortical origin, occasionally next to the protective sheath itself, but that in the upper part of the older sporophyte there is a layer of cells which belongs to the central cylinder lying between the protoxylem and the cells of cortical origin, and probably representing phloem-cells. This latter condition agrees with that of the mature stem, where there is generally a ring of thin-walled cells lying between the protoxylems and the endodermis which resemble the cells surrounding the sieve-tubes between the xylem rays. The view that this layer outside the xylem represents phloem does not seem inconsistent when one considers the irregular course which the xylem strands take through the stem of the young sporophyte, and the fact that the leaf-traces play an important part in the constitution of the central stele, except in the lower part of the young sporophytes.

According to Campbell ${ }^{2}$ the complete stem of Lycopodium possesses two systems of vascular bundles, the strictly cauline central cylinder and the system of common bundles formed by the leaf-traces.

In the lower part of the young sporophyte the central stele is strictly cauline. The first indication of anything approaching a leaf-trace is the spiral marking of some of the cortical cells which are in connexion with the base of the scale. In a slightly more advanced stage the leaf-trace is represented by exceedingly narrow tracheides which leave the main stele at the edge of one of the protoxylems. Higher up, where the leaves have reached the light and are better developed, the structure of the leaf-trace is more complicated, the number of elements increasing as it passes through the cortex. The leaf-trace leaves the main stele at the end of the xylem plates and takes an upward course through the cortex, making an acute angle with the central stele of the stem, while near the periphery it takes a more horizontal course. A section taken just above the point where it leaves the stele of the stem shows a well-defined mass of xylem consisting of tracheides which in transverse section appear to be full of granules owing 
to the ingrowth of the thickened part of the wall ${ }^{1}$ (Pl. XXII, Fig. 17), these are surrounded by elongated parenchymatous cells with large nuclei, which connect up with the ring of parenchyma which surrounds the main stele and which appears to be of the nature of phloem, although true sieve-tubes have not been made out in the leaf-trace. Russow ${ }^{2}$ states that the leaf-trace in Lycopodium consists of a few spiral and reticulate cells, which are surrounded by companion cells and a few protophloem elements. In the young sporophytes I examined the elements forming the leaf-trace were so small that I was unable to distinguish sieve-plates in the elongated cells surrounding the xylem.

When the leaf-trace has passed beyond the endodermis it can be seen that the number of elements surrounding the xylem has increased, and that some of the walls of the 'phloem' cells have become thickened, so that it is difficult to distinguish between the xylem and the remaining elements in transverse sections, as the walls of the xylem elements contain little or no lignin. The increase in the number of elements forming the leaf-trace is not peculiar to this species. It is well marked in L. Phlegmaria, which possesses very large leaf-traces, and here it can be clearly seen that the leaf-trace is surrounded by a protective sheath of cells resembling those surrounding the central cylinder of the stem, and that they have divided by walls parallel to the periphery of the bundle.

Bower ${ }^{3}$ found that, amongst the species of Lycopodium he examined, the leaf-trace of L. Phlegmaria most resembled that of Lepidostrobus Brozenii, both with regard to the small amount of tissue referable to phloem and the division of the outer cells by walls parallel with the limits of the bundle. Tmesipteris also shows a resemblance in these respects. The leaftrace of Lepidostrobus Brownii is, however, collateral, and in recent Lycopods it appears to be concentric.

(c) Comparison of the stem of the young sporophyte zith that of the mature plant. Comparing the structure of the stem of the young sporophyte of $L$. complanatum with that of the mature plant, it will be seen that the stele in the upper part of the branches of the latter closely resembles that of the upper part of the young sporophyte in there being 3-5 protoxylem groups radially arranged and connected by metaxylem in the centre, with usually one or more groups separated off from the rest and surrounded by a layer of parenchyma. The chief differences lie in the irregular and rapidly changing arrangement of xylem and phloem in the basal portion of the stem of the young sporophyte, and in the shape of the stem-that of the young

'De Bary describes somewhat similar tracheides, which he calls 'trachae trabeculatae,' as occurring at the corners of the vascular bundle of the stems of stronger species of Lycopodium, and in the margin of the vascular bundles of the leaves of Juniperus. Compar. Anatomy of Phanerogams and Ferns, pp. $16_{3}, 16_{4}$, Fig. 62 .

${ }^{2}$ Russow, Mém. de l'Académie Impériale des Sc. de St-Pétersbourg, $7^{\mathrm{e}}$ Sér., vol. xix.

${ }^{3}$ Bower, On Structure of Lepidostrobus Brownii. Ann. of Botany, vii, 1893, p. $34^{\circ}$. 
sporophyte being more or less round in transverse section, while that of the mature plant is like a flattened triangle, owing to the shape of the leaves and their fusion with the stem. They are fused in such a manner that the chief part of the cortex, consisting of radially elongated assimilating cells, belongs equally to the leaves and stem, and this distinguishes the cortical tissues from those of the young plantlet, in which the assimilating cortical cells run in a vertical direction. Another difference lies in the distribution of the stomata ; these occur all round the stem of the young sporophyte, but are confined to the flattened ventral side of the mature stem. The creeping underground part of the stem of the mature sporophyte naturally shows greater differences. Here the stem is much more bulky and circular in transverse section; the number of protoxylem groups has increased to a dozen or more, and these are connected in twos or threes by metaxylem in such a manner that the well-known banded arrangement is produced. The parenchymatous zone round the xylems is more pronounced, and the walls of the cells of the inner cortical zone have thickened so much that only very small lumina are left. The presence of large intercellular spaces in the surrounding cortical layers and stomata in the epidermis, together with the fact that small leaves provided with vascular bundles occur at intervals, indicate an ancestral condition in which this part of the stem was also aerial. Evidence drawn from the study of the young sporophyte seems to point to the view that the radial arrangement of xylem and phloem occurring in the upright form of Lycopodium is the more primitive condition, and this is supported by evidence from fossil forms of the Lycopodiales.

(d) Branching of the Stem. The branching of the stem, as in the roots, is dichotomous. This may begin very early, but in most cases the growth of one of the branches is stronger than that of the other, and so sections taken immediately below the dichotomy show one of the two steles smaller than the other. In the case of the pseudo-adventitious bud, the growth of one of the branches of the dichotomy is arrested for a considerable period, and it remains as a bud protected by a few leaves until favourable circumstances arise for the continuation of its growth, and then not only apical growth occurs, but a root may be produced at the base, $r t$. Pl. XXII, Fig. ${ }_{5}$, so that if separated off from the main plant it could lead an independent existence.

(e) The Apex of the Stem. Longitudinal sections were made through the apex of the sporophyte shown in Pl. XXII, Fig. 2. This had dichotomized, and one of the branches had grown rather longer than the other. The shorter branch had just dichotomized, and showed at the apex two smaller groups of cells forming somewhat flattened cone-shaped structures about equal in size. A definite apical cell could not be made out; the actual apex appeared to be occupied by several large cells equal in size, from which, 
first by periclinal walls and then anticlinal, the cells which give rise to: the various tissues of the stem are cut off.

\section{The Leaves.}

The first leaves of the sporophyte are of very simple structure. They are merely scales consisting of small cells, rounded near the apex and becoming more elongated when they join on to the stem.

In the smaller sporophyte of $L$. complanatum shown in PI. XXII, Fig. 1, although a number of these scales were produced, there was no trace of a vascular bundle in any of them. They were not more than three cells in thickness at the widest part, and the central row appeared in no way different from the outer ones. A longitudinal section near the apex of the shoot showed a few very long, spirally marked cells, running from the stele of the stem to the base of the scale-leaf.

In the older sporophyte (Pl. XXII, Fig. 2) the differentiation of the leaftissues had begun earlier; probably this was connected with the formation of a pseudo-adventitious bud. The stem had evidently dichotomized above the foot. In a series of sections cut through this region the first leaf appears as a scale, without any vascular bundle, opposite to the point where the first root leaves the stem. The second leaf appears slightly higher.up, about a quarter of the distance round the stem. I could not verify the description of Bruchmann ", according to which the first two leaves are opposite, as in Selaginella. The same series of sections shows dichotomy of the stele completed, and the third leaf appears on the side of the arrested branch. About the same time a leaf cut longitudinally shows a very simple vascular strand consisting of a few very narrow tracheides, the continuation of which can be traced as far as the protective sheath of the central cylinder. Higher up, the differentiation of the tissues of the leaves is more marked, but they do not attain a great degree of complexity in the young sporophyte.

The vascular bundle of the leaf extends about four-fifths of the length of the leaf; it is made up of a few spiral or reticulate tracheides, which are, in the lower part of the leaf, surrounded by narrow elongated cells with thickened walls, of the nature of tubes containing granules, and in some cases nuclei ( $p h$, Pl. XXII, Fig. x 8 ), and of parenchymatous cells, some of which contain chlorophyll corpuscles.

Erikson $^{2}$, in his paper on the anatomy of the leaves of the Lycopodiaceae, notes that in many forms the outer bast cells contain chlorophyll, but does not mention $L$. complanatum in this connexion. He distinguishes four types of bast as occurring in the leaves of the Lycopodiaceae ${ }^{3}:-$ - (I) thickwalled and lignified bast, as in L. annotinum and clavatum ; (2) thick-walled

1 Bruchmann, loc. cit., pp. 53, 68.

${ }^{2}$ Erikson, Arbeten från Lunds Botaniska Institution, 1892.

s Erikson, loc. cit., p. 35 . 
and unlignified as in $L$. rufescens; (3) singularly thin-walled bast, as in L. guidoides; (4) bast with thin walls in the interior and thick-walled on the exterior, as in L. tetragonum. He includes $L$. complanatum in the same group as $L$. annotimum, L. clavatum, L. magellanicum, and L. alpinum, forms which are characterized by their very woody bast, slanting palisade cells, and strongly developed stomata. I was unable to detect lignification in the walls of the bast-cells of $L$. complanatum, but they appear thickened.

A definite endodermis was not distinguishable in the leaves of $L$. complanatum, and the bundle elements seemed to gradually merge into the more loosely and irregularly arranged parenchyma forming the mesophyll. Stomata occur on both upper and under sides of the leaf of the young sporophyte.

The leaves arise very close together, and are irregularly arranged in four rows round the stem. They begin as small projections formed by two or three of the epidermal cells near the apex growing in a radial direction, and rapidly dividing by periclinal and anticlinal walls. In the very early stage an apical cell appears, and from this cells are cut off for the upper and under side of the leaf, while periclinal walls cut off cells for the central tissue; at the same time there is active division taking place at the base of the leaf, and while, after a time, the apical cell ceases to divide, intercalary growth at the base continues until the leaf has reached its full length. At a very early stage the cells bordering the apex begin to elongate, forming the long tapering point characteristic of the mature leaves, and the differentiation of the vascular strand soon begins. In the stem the tracheides of the leaf-trace are the first to appear; they occur at the periphery of the central stele and then run obliquely upwards through the cortex of the stem, extending towards the tip of the leaf, but never quite so far as the actual apex.

Stomata are developed on both sides of the leaf, and, as the leaf grows, air-spaces become more numerous, especially in the lower region, and are connected with the air-spaces of the stem, the cortex of the stem passing insensibly into the bases of the leaves.

The leaves of the young sporophytes of $L$. complanatum show considerable differences from those of the aerial part of the mature plants, both in arrangement and general structure.

In the young sporophytes they are arranged in four rows in an irregular spiral manner, often two leaves occurring opposite or almost opposite each other, but at the base considerable internodes generally intervene. They are all linear lanceolate in form, the lower half of the leaf closely adhering to the stem. In the mature plant the leaves are crowded together, and fused with the stem in such a manner that one cannot tell where the leaf ends and the stem begins; only a small portion of the leaf is free from the stem. They are arranged very regularly in four rows 
round the stem, and owing to the dorsiventrality of the latter, three different kinds must be distinguished, exposed to different degrees of light, moisture, $\& c .$, namely, dorsal, ventral, and lateral leaves. The ventral leaves are narrow, and gradually taper to a point; a very small portion of the leaf is free from the stem, the remaining part is fused with it in such a manner that the division between the two is at once lost sight of, and the whole ventral side of the shoot appears slightly concave.

The dorsal leaves are also long and narrow, but the tapering near the apex is more sudden than in the ventral leaves, and the portion of the leaf fused with the stem projects from the surface of the shoot until it is hidden by the free part of the next leaf below.

The lateral leaves are arranged in pairs almost opposite to each other ; they are keeled, and only a very small portion of the leaf is free from the stem. The free portion tapers gradually to a point, and is triangular in transverse section; the fused portion is extensive, and appears to form the chief assimilating organ.

Comparing the distribution of stomata on the leaves of the mature plant and those of the young sporophyte, it appears that whereas on the latter the stomata are scattered in about equal numbers on both surfaces, in the former their distribution is restricted to certain areas. On the outer side of the ventral leaves stomata occur only on the basal portion, while on the inner side they are scattered over the surface, almost extending to the apex. On the outer side of the dorsal leaves stomata are absent, while on the inner side they are restricted to a small area a short distance below the tip. In the case of the lateral leaves, three surfaces must be considered - upper, under, and inner, the two former representing the outer surface of the leaf. On the under side numerous stomata occur near the base of the free portion, especially on that part which lies nearer the stem, and on the fused portion except near the outer edge. Stomata are absent on the upper side, but are present on the inner surface of the leaf. The vascular bundle does not appear to differ materially from that of the aerial leaves of the young sporophyte described above.

\section{SUMMARY.}

The main results obtained during this investigation may be summarized as follows :-

I. The first root of the young sporophytes of $L$. complanatum and L. clavatum may show a monarch, diarch, and triarch arrangement in the same plantlet; the xylem groups are usually separated by phloem, which occupies the centre of the stele and extends between the xylem groups to its periphery.

2. The second and following roots show a diarch arrangement, except the fine ramifications, which are monarch. 
3. The roots arise endogenously near the apex of the stem, except the first root, which, according to Bruchmann, arises endogenously from the base of the 'hypocotyl.' The growth of the roots formed at the apex remains arrested for a time, and then they either grow out at right angles to the stem or they may take a downward course through the cortex of the stem.

4. The branching of the roots appears to be a form of dichotomy, but one branchlet is generally less vigorous than the other, and receives a smaller strand of vascular tissue.

5. In $L$. complanatum a short strand from the main stele passes into the foot, and the appearance of the peripheral cells of the latter is such that the possibility that it may still act as an absorptive organ after the disappearance of the prothallus is not excluded.

6. The arrangement of the vascular tissues at the base of the stem shows much irregularity. The xylem strands appear to be continuous with those of the first root, and an arrangement very similar to that occurring at the base of the root may be seen immediately above the point where the root comes off. At this point a fusion of two or of all three xylem strands takes place.

7. The xylem strands take a very irregular course, fusing with one another and subdividing in the lower part of the stem, probably due to the frequent bending in this region.

8. The upper part of the stem shows a tri- or tetrarch arrangement of xylem with central metaxylem, generally connected with two or more groups of protoxylem.

9. The apex of the stem is occupied by several large actively dividing cells.

IO. Branching of the stem takes place by dichotomy, but the growth of one of the branches is generally stronger than that of the other; the retardation of one of the branches may result in the formation of a pseudoadventitious bud in the case of $L$. complanatum.

II. The first leaves are scale-like, without vascular bundles, and arranged in an irregular spiral round the stem. The later leaves have a vascular strand, which consists of a few very narrow tracheides surrounded by a more or less thick-walled bast.

In conclusion, I should like to add that this investigation was undertaken at the suggestion of Professor Weiss, to whom my best thanks are due for the valuable suggestions and advice which he has given me throughout. I also wish to express my thanks to Dr. Bruchmann for his readiness in agreeing to the publication of this investigation, made upon material generously supplied by him and intended primarily for museum purposes. 


\section{EXPLANATION OF PLATE XXII.}

\section{Illustrating Miss Wigglesworth's Paper on Lycopodium.}

Figs. I and 2. L. complanatum. Young sporophytes. $r^{1}=$ first root, $r^{2}=$ second root, $f t=$ foot, $p a=$ psendo-adventitious bud, $l^{1}$ and $l^{2}=$ first and second scale-leaves. Fig. I $\times \mathrm{I}$, Fig. $2 \times \mathrm{I} \frac{\mathrm{I}}{2}$.

Fig. 3. L. complanatum. Transverse section through root showing two groups of xylem. $e n=$ protective sheath, $p c=$ pericambium, $p x=$ protoxylem, $p h=$ phloem. $\quad \times \mathrm{I}_{5} \mathrm{O}$.

Fig. 4. L. clavatum. Portion of a transverse section through the lower part of stem showing a diarch rootlet in the cortex. $r t=$ rootlet, $p x=$ protoxylem, $m x=$ metaxylem, $p h=$ phloem, $e p=$ epidermis of stem. $\times \mathrm{I}_{4}$.

Fig. 5. L. complanatum. Transverse section through central region of rootlet showing two xylem groups fused, forming a crescent-shaped mass. Lettering as in Fig. 3. $\times 200$.

Figs. $6,7,8$. L. complanatum. Transverse sections through central region of rootlet showing hranching. In Fig. 6 the xylem of smaller branch separates off from two groups of xylem which have previously fused to form a crescent-shaped mass; in Fig. 7 it comes off from only one of the xy'em groups; Fig. 8 shows the xylems of the two branches completely separated. Lettering as in Fig. 3. $\times 200$.

Fig. 9. L. complanatum. Portion of transverse section through basal region of first root showing three groups of xylem. $c p=$ epidermis, $c=$ cortex, i.s. $=$ intercellular space, $p c=$ pericambium, $e n=$ protective sheath, $p x=$ protoxylem, $p h=$ phloem. $\times 300$.

Fig. 10. L. complanatum. Portion of transverse section through lower region of stem showing young rootlet. $e p=$ epidermis of stem, $i_{.} s_{0}=$ intercellular space, $c=$ cortex, $e n=$ protective sheath. $\times$ I09.

Fig. II. L. clavatum. Transverse section through stem at a slightly higher level than that shown in Fig. 4 showing connexion of the rootlet stele with that of the stem. $r t=$ rootlet, $s t=$ outer tissues of stem. $\times 90$.

Fig. I 2. L. complanatum. Transverse section through foot region. $p=$ remains of prothallus, $e n=$ protective sheath, $t=$ tracheide. $\quad \times 7 \mathrm{I}$.

Fig. I3. L. complanatum. Transverse section through central region of foot at a slightly higher level than that shown in Fig. I2. Lettering the same as in Fig. I2. $\times 150$.

Fig. I4. L. complanatum. Transverse section through lower region of stem showing isolated central metaxylem and three groups of protoxylem at the periphery of the stele. A leaf is cut longitudinally and a portion of the leaf-trace is shown. $l t=$ leaf-trace, $l=$ leaf, $p c=$ pericambium, $e n=$ protective sheath, $i c=$ inner cortex, $m c=$ middle cortex, $c p=$ epidermis. $\quad \times \mathbf{8 2}$.

Fig. I5. L. complanatum. Transverse section through stem and pseudo-adventitious bud ( $p a$ in Fig. 2) showing main branch of stem $(a)$ and retarded branch $(b)$ which has produced a root $(r t)$. $l=$ leaf. $\quad \times 7 \mathrm{I}$.

Fig. 16. L. complanatum. Xylem elements of stem in longitudinal section.

Fig. I7 $a, b, c$. L. complanatum. Successive transverse sections through the peripheral portion of one of the xylem rays and the surrounding tissues in the upper part of the stem showing outgoing leaf-trace, the dotted cells represent the curiously thickened tracheides of the leaf-trace. In I7 $c$, where the leaf-trace tracheides have become separated from the main xylem mass, they are surrounded by cells with large nuclei which apparently represent phloem. en $=$ protective sheath, $l t=$ leaf-trace, $p h=$ phloem, $p x=$ protoxylem. $\times 147$.

Fig. 18. L. complanatum. Part of a longitudinal section through a leaf on the upper part of the stem showing thick-walled phloem. $\quad e p=$ epidermis, $m=$ mesophyll, $i . s .=$ intercellular space. $t=$ tracheide, $p h=$ phloem. $\times 247$.

Fig. 19. L. complanatum. Transverse section through the central tissues of leaf from upper part of the stem. The vascular bundle is represented by thick-walled cells, the outer ones of which contain protoplasm and represent phloem $(p h) . \times 187$.

Fig. 20. Phylloglossum Drummondi. Transverse section through stele of a root. $e n=$ endodermis, $p x=$ protoxylem, $p h=$ phloem.

Fig. 21. Lycopodium Hippuris. Sieve-tubes in longitudinal section. $\times 600$. 
Annals of Botany.
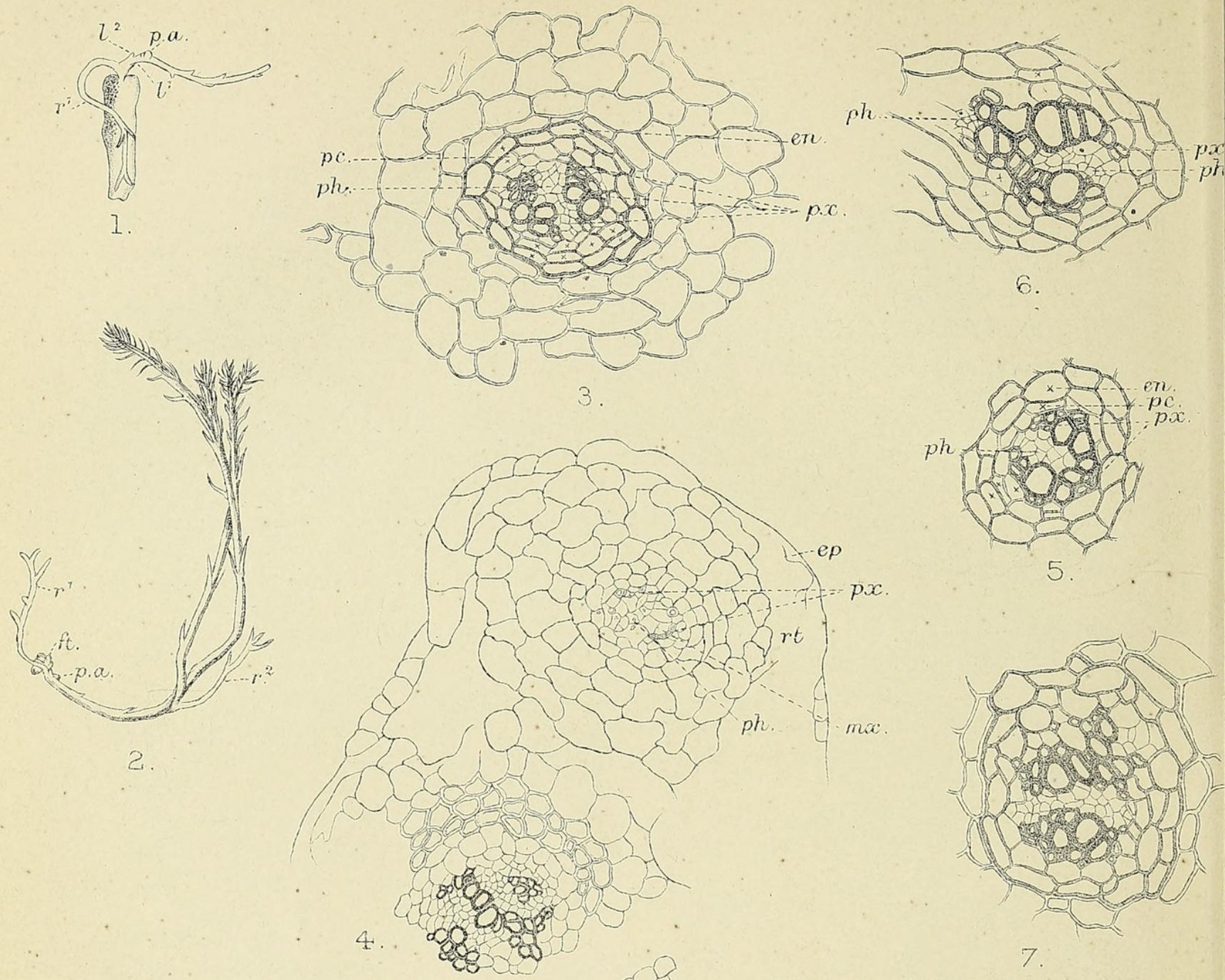

6.


8.

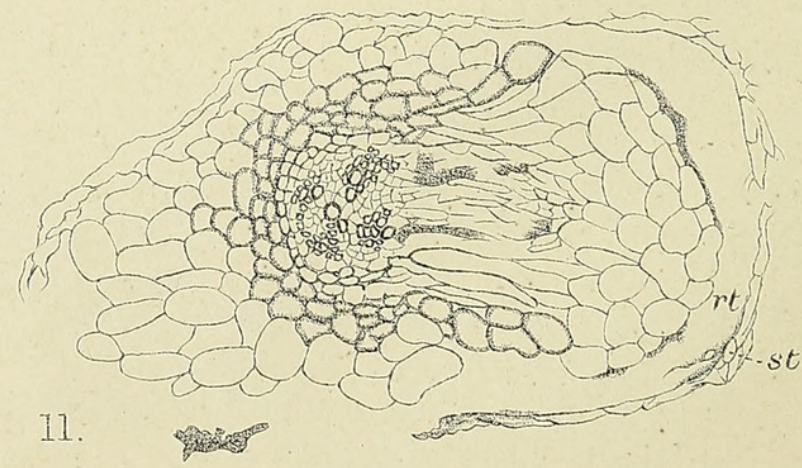



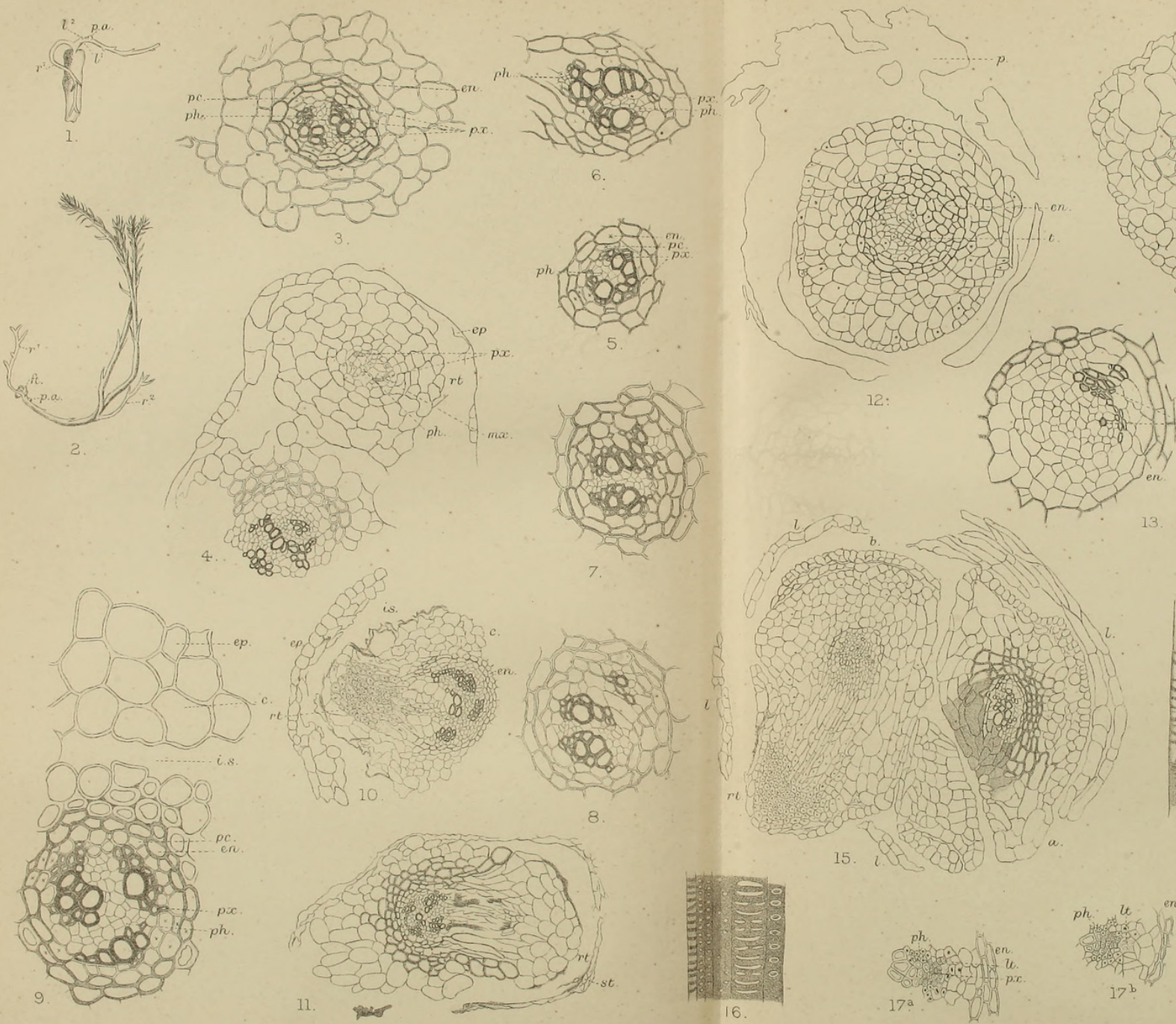

15. 1 कि
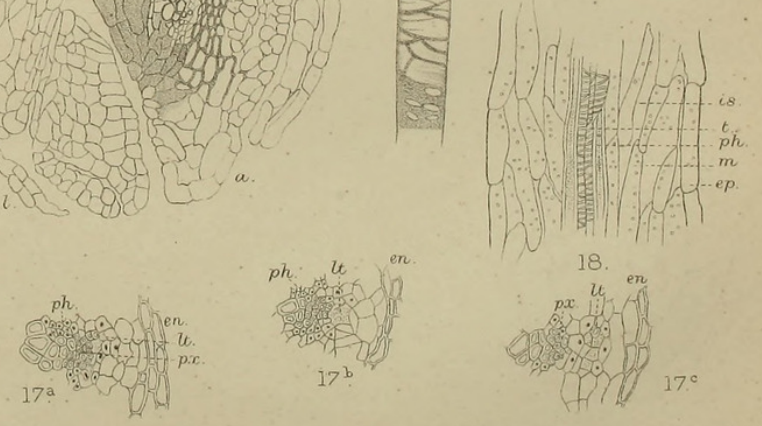


\section{$2 \mathrm{BHL}$ Biodiversity Heritage Library}

Wigglesworth, Grace. 1907. "The young sporophytes of Lycopodium complanatum and Lycopodium clavatum." Annals of botany 21, 211-234. https://doi.org/10.1093/oxfordjournals.aob.a089131.

View This Item Online: https://www.biodiversitylibrary.org/item/235747

DOI: https://doi.org/10.1093/oxfordjournals.aob.a089131

Permalink: https://www.biodiversitylibrary.org/partpdf/318870

\section{Holding Institution}

Smithsonian Libraries

\section{Sponsored by}

Biodiversity Heritage Library

\section{Copyright \& Reuse}

Copyright Status: Not in copyright. The BHL knows of no copyright restrictions on this item.

This document was created from content at the Biodiversity Heritage Library, the world's largest open access digital library for biodiversity literature and archives. Visit BHL at https://www.biodiversitylibrary.org. 